\title{
Environmental awareness in China: Facilitating the greening of the economy
}

\author{
$\underline{\text { Guo, X. and D. Marinova }}$ \\ Curtin University Sustainability Policy (CUSP) Institute, Curtin University, Western Australia \\ Email:X.Guo@curtin.edu.au
}

\begin{abstract}
China's miraculous economic growth (at an average rate of 10\% per annum for over three decades) has come under a strong criticism because of the country's increasing environmental deterioration. In 2007, China officially became the top global greenhouse gas (GHG) emitter and its natural environment has suffered severe deterioration while the country's governments had been focusing predominantly on economic growth without paying significant attention to the ecology. Recently however with the country's $12^{\text {th }}$ Five-Year Plan the government adjusted China's national development strategy towards addressing climate change and achieving a low-carbon economy which considers the global impact from the country's economic development. The foundation for developing a low-carbon economy in China lays in enhancing its environmental education system and overall environmental awareness.
\end{abstract}

This paper analyses the increase in environmental awareness in China based on the conceptual sustainability model. It uses data to describe community, government and media engagement with environmental issues and analyses the trends in activities, such as public petitions, government reports and media news/articles. It shows that the government has gradually increased the attention paid to environmental issues, including adopting a wide range of new policy documents and encouraging environmental education programs. Protecting the environment has also become a highly important topic of media coverage in all Communist Party controlled provincial newspapers with overall more than 8,000 counts of environmentally related news/articles in 2009 (or around 22 per day) and the two main Chinese newspapers, Beijing Daily and Liberation Daily providing highly comprehensive environmental reports. Public participation around ecological issues has also been on the rise with high numbers of environmental petitions and proposals reaching the National People's Congress (NPC) and the Committee of the Chinese People's Political Consultative Conference (CPPCC).

The paper concludes that despite the fact that environmental awareness and environmental concerns have become more and more visible within the Chinese society, there is still a strong need to improve environmental education and government policies in order to achieve a harmonious transformation of China's economy. For example, a lot more scientific, technological and managerial personnel for environmental protection work should be provided by the Chinese higher education system to accommodate the need for developing a low-carbon economy. Also, in the search of solutions the Chinese governmental and non-government organizations can be involved in developing a better relationship between people and their natural environment by absorbing nourishment from the Chinese cultural genes, such as the ancient wisdom of Confucianism. Although China has set up high goals to achieve and has already established a complete environmental management system, this country is still in need of a better environmental awareness and effective implementation of environmental management, laws and regulations.

Keywords: carbon emission, environmental education, media, NGOs, publicity 


\section{INTRODUCTION}

China is the most populous and the fastest growing developing country in the world. In the past three decades, the country has been on a trajectory of unstoppable economic expansion in order to achieve economic prosperity. Its rapid industrialisation and urbanisation however have caused extensive environmental deterioration. In 2007 the country became the world largest greenhouse gas (GHG) emitter.

China's level of carbon emissions has increased due to the continuous industrialisation, urbanisation and technologies used, which have increased sharply energy demand (UNDP China, 2009). Its per capita carbon dioxide $\left(\mathrm{CO}_{2}\right)$ emissions are just above the world average (International Energy Agency, 2009), but its global impact is massive due to the size of its fast growing population. According to the International Energy Agency (2009), China's $\mathrm{CO}_{2}$ emissions have almost tripled between 1990 and 2007. Despite reduction in emission intensity, the country's continuous economic growth has been triggering a sharp increase in the levels of $\mathrm{CO}_{2}$ emissions per capita (see Figure 1).

There was an urgent need for changing the economic growth model to a more sustainable one and in 2009 China made its first announcement of a concrete quantifiable target of reducing the intensity of $\mathrm{CO}_{2}$ emissions per unit of GDP. Environmental protection became the focus in the country's $12^{\text {th }}$ National Plan (2011-2015), which set an energy intensity reduction target of $20 \%$ and a major pollution reduction target of $10 \%$ by 2010 against a 2005 baseline. China further updated and deepened its commitment to reducing the intensity of $\mathrm{CO}_{2}$ emissions per unit of GDP in 2020 by $40-45 \%$ against the 2005 level.

To sustain a high economic growth while developing on a low-carbon pathway and drastically changing the habits of the past, the environmental consciousness of Chinese people needs to be boosted. This study explores the roles of Chinese government and non-government organisations in promoting environmental awareness. Because of China's significance to the world's economy and ecology, these developments are very important from an international perspective. Sustainable growth in China is one that integrates active economic growth with care for the natural environment and natural resources in order to improve the quality of life. Enhancing environmental awareness becomes extremely important for achieving this but the reality so far has been that this has been left behind in the country's economic race.

\section{CHINA'S ENVIRONMENTAL STATE}

China's natural environment has suffered severe deterioration while the country's governments had been focussing on economic growth without paying enough attention to the ecology. Air-pollution problems in Chinese cities have become more and more serious (UNEP, 2009). Water pollution in major water basins has attracted escalating domestic and global attention $(\mathrm{Wu}, 2010)$. The growing population in sprawling cities, such as Chongqing with a population of over 30 million, challenges the urban standards of energy efficiency and required infrastructure. The predominantly coal-based economy has been causing increases in health related problems. According to Hickson (2009, p 491) "China is expected to remain dependent on coal for about $70 \%$ of its energy needs for at least the next two decades, and remain the world's biggest emitter of carbon dioxide."

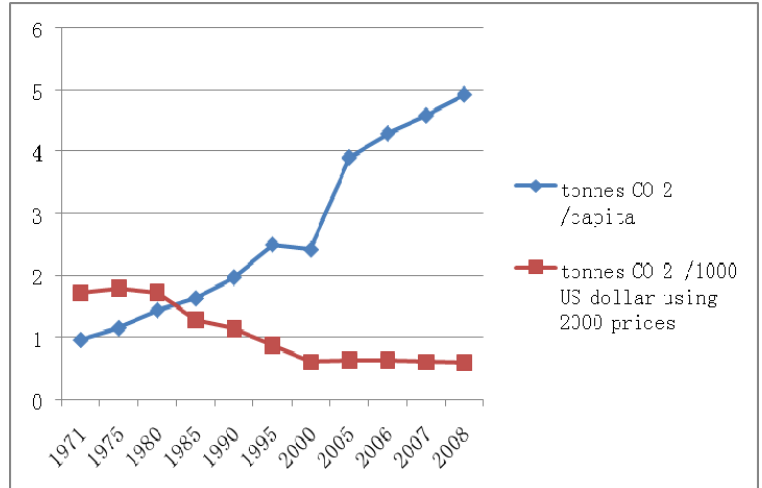

Figure 1. $\mathrm{CO}_{2}$ emissions per capita and $\mathrm{CO}_{2}$ emission per GDP in China, 1971-2008 Source: International Energy Agency (2010)
China is facing the consequences from degradation of its natural environment, including serious water pollution and deteriorating urban environments. Concern for China's environmental issues keeps growing due to the increasing carbon emissions from industries and vehicles. The intensity of the exploitation of natural resources and poor technology and management in China are causing serious environmental pollution and ecological destruction. The rapid growth of China's economy has resulted in many ecological and environmental issues, such as: depletion of non-renewable resources, deterioration in land quality, destruction of landscapes, soil and deteriorating urban environments.

The country's prospects remain bleak under a business-as-usual scenario. Therefore there is an urgent need for China to take actions to enhance the level of environmental awareness and education if it is to develop a low-carbon economy. 


\section{CHINA'S SHIFT TO A LOW-CARBON ECONOMY}

China was the first developing country to announce in 2007 a national plan addressing climate change. In 2009 , it set not only an ambitious target of reducing $\mathrm{CO}_{2}$ intensity but also to become a leading country in developing a low-carbon economy (Xinhua Net, 2009). In 2011, China's $12^{\text {th }}$ Five-Year Plan highlights a green path of development and aims to ensure that the country's energy consumption per unit of GDP and $\mathrm{CO}_{2}$ emissions fall significantly and its ecological environment is distinctly improved (China Daily, 2011).

A low-carbon economy refers to an international comparison of carbon intensity per unit of production and "maximises carbon productivity, improves capacities for adaptation to climate change, minimises the negative impacts of climate change, improves human development, and accommodates both inter- and intragenerational needs, thereby laying the foundation for sustainable socio-economic development" (UNDP China, 2010, p 5). A low-carbon economy aims at meeting global standards, which is distinct to green economy, ecological economy, circular economy or industrial ecology, which look at $\mathrm{CO}_{2}$ emissions from a domestic environmental perspective; the low-carbon economy considers the global impact.

One implication from such a perspective are technological choices, which is particularly relevant to China as "the large variations in energy and carbon productivity between the developed and developing worlds highlight the need for low-emissions technologies to flow to the developing world" (McKinsey Global Institute, 2008, p 35). The United Nations warned that China faces no other choice but to transform to a lowcarbon economy to meet its future social and economic development targets (UNDP China, 2010). China's $12^{\text {th }}$ Five-Year Plan has given priority to low carbon energy, energy efficiency and clean technology. Increasing carbon productivity is a strategy being adopted at all levels of government in China at the moment. A number of cities have put forward a vision of transforming to low-carbon cities (National Development and Reform Commission, 2009). The Shanghai Expo, which led the low carbon awareness in China, is also influencing the rest of the country positively. China will continue to develop a low-carbon economy through cooperation with developed countries, including Australia (Australian Government, 2011).

China's adoption of a low-carbon economy model proves its understanding of the importance and urgency of the tasks but also its willingness to consider its development strategy from a global perspective. Whether or not China's new strategy will be achieved successfully in the future depends largely on a widespread environmental awareness. The foundation for developing a low-carbon economy in China lays in enhancing its environmental education system. Only a decade ago after serious ecological damage had already been done, has environmental awareness entered the attention of policy makers. Despite some progress made there is a long road ahead with the need for clear signposts and responsibilities.

\section{ENVIRONMENTAL AWARENESS IN CHINA}

The issue about environmental education in Chinese schools was first raised in 1979 by the Chinese Association of Environmental Science and in 1983 environmental protection became China's basic state policy. However it took until 2001 for the Ministry of Education to develop a country-wide model and until 2003 for its unified curriculum to be activated (McBeath and McBeath, 2009). Elementary and middle schools began to emphasise local issues, such as pollution and ecological disasters but also the connection between the global and local environment (Qing, 2004). Environmental non-governmental organisations (NGOs) have increasingly started to play a unique and significant role in environmental education and awareness in China. Friends of Nature, the country's first environmental NGO, was founded in 1994 and by 2005 the number of various environmental organisations reached 2,768 (Xu, 2009). According to Harris (2006), China has been making some of the world's most profound environmental changes. Improving environmental education, awareness and attitudes is extraordinarily important and a multitude of players, ranging from government organisations and institutes to NGOs and the media, are contributing for this transformation. Undertaking carbon reduction related environmental education and awareness programs is now very high on the political agenda.

\subsection{Governmental Organizations and Institutions}

In order to achieve environmental protection objectives and mobilise the public for achieving a low-carbon economy, deeper environmental publicity and education are needed. In 1996, China undertook the Platform for Action, the National Environmental Publicity and Education (1996-2010) program (National Environmental Protection Bureau et al., 1996) to improve environmental education and encourage citizens to protect the environment. Since then every 5 years the Chinese government undertakes this educational program to strengthen the nation's environmental awareness and achieve a high level of public environmental awareness. The Environmental Education Programs are carried out through promoting environmental 
education in schools, adult education, publishing brochures, mass media and activities targeting ordinary Chinese citizens as well as business people and students. China's collaborative endeavour to popularise environmental protection knowledge nationwide has been gradually raising people's environmental consciousness (State Council Information Office of China, 2006). The government has gradually increased the attention paid to environmental issues as manifested in the number of policy documents (Huang et al., 2010 and Figure 2).

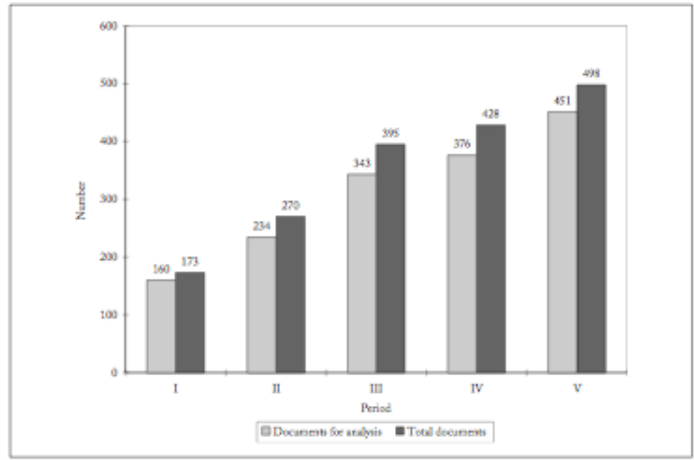

Periods: I-1999-2000, II-2001-2002, III-2003-2004, IV-20052006 and $\mathrm{V}-2007-2008$

Figure 2. Government documents on environmental issues; Source: Huang et al. (2010)
However a lot more scientific, technological and managerial personnel for environmental protection work should be provided by the Chinese higher education system to accommodate the need for developing a low-carbon economy. Furthermore, secondary and vocational high schools should offer more environmental courses. A large number of environmental specialists need to be trained; as well as on-job-training programs need to be offered. Environmental education should be provided to everybody but business people require particular attention. The low-carbon economy is a relatively new concept for China where the government has been concentrating mainly on economic prosperity and efforts are needed from Chinese governmental agencies and industry for this to be achieved.

\subsection{Media and Environmental Public Participation}

Media can be a powerful platform for enhancing environmental education in China and in recent years they, particularly the newspapers owned by the individual provincial governments, have been performing this role increasingly better. The mass media not only encourage public concern for environmental issues and actively create public awareness (Parlour and Schatzow, 1978) but also trigger most needed responses. For example, information discloser is becoming an important method for pollution control and encourages enterprises to take more environmental responsibilities (Uchida, 2007). After an incident of environmental damage is disclosed in the media, this generates a lot of public opinion pressure on the polluter as well as on the local government to which they will have to respond by taking appropriate measures for improvement. A positive environmental publicity on the other hand plays a significant role in public environmental education and guidance.

Protecting the environment has gradually become a highly important topic of media coverage in all Communist Party controlled provincial newspapers. These newspapers play an important role in public environmental publicity and they are also the tools of supervising and reporting the incidents of environmental damage. The number of environmentally related news/articles in each provincial newspaper reflects the level of the region's environmental information disclosure. Figure 3 presents the trends in environmental related news and articles in the 30 Chinese provincial newspapers over the 2003-2009 period. Despite a small decline in 2009, the overall trend in all regions is upwards with overall more than 8,000 counts in 2009 (or around 22 per day). This is a sharp four-fold increase from the 2,000 news/articles (or just about 5 per day) in 2003 .

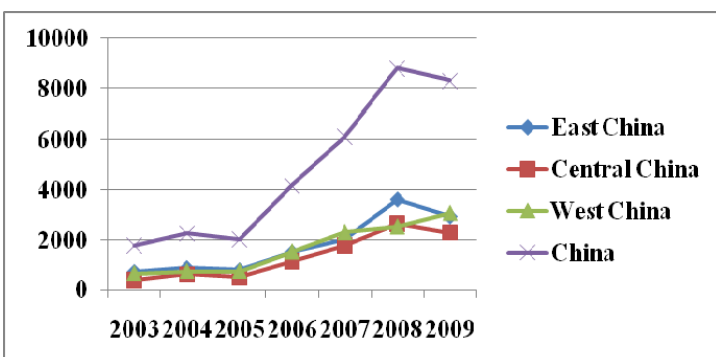

Figure 3. News/articles related to environmental protection in provincial newspapers in China, 2003-2009

Data source: Duxiu.com

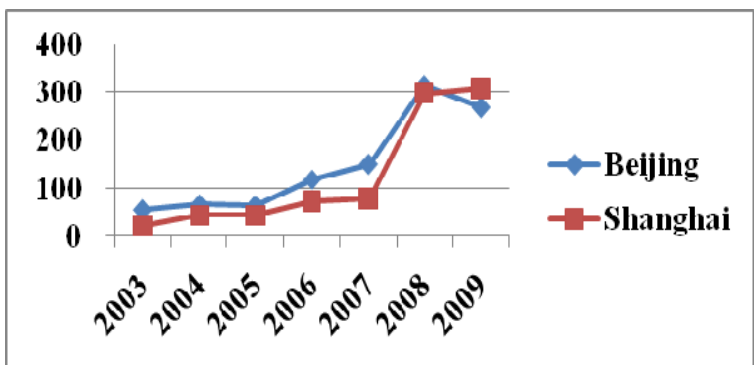

Figure 4. News/articles related to environmental protection in Beijing Daily (Beijing) and Liberation Daily (Shanghai) 2003-2009

Data source: Duxiu.com 
Of particular interest is the media coverage of environmental issues in the two main Chinese newspapers, namely Beijing Daily in Beijing and Liberation Daily in Shanghai. They have a large circulation nationwide (as well as internationally), provide highly comprehensive reports and have the most powerful influence in the country. The number of environmentally related news and articles in both newspapers has drastically picked up since 2007 (see Figure 4).

The public is the beneficiary from environmental protection and has the power to push the right formulation of environmental policies as well as to supervise their effective implementation. Figures 3 and 4 indicate that the media disclosure rate of environmentally related news/articles reached a peak in all regions in 2008, which was due to the influence of the 2008 Beijing Olympic Games. This also shows that international involvement can encourage better environmental consciousness and wider environmental publicity through mass media. These trends have further proved the research evidence emerging that wealthier parts of the country are more likely to pay more attention to ecological health and education (Wei et al., 2010).

\subsection{Environmental Petitions and Proposals}

Environmental petitions and environmental proposals submitted to the National People's Congress (NPC) and the Committee of the Chinese People's Political Consultative Conference (CPPCC) each year are a good indicator for the level of the public environmental participation and consciousness. A high frequency of petitions reflects a higher level of hot environmental issues raising serious concerns while the number of proposals is indicative of measures taken to protect the environment, prevent or rectify ecological damage.

Figures 5 and 6 show that there is a lot of activities happening in relation to the natural environment in China, particularly in its Eastern provinces. It seems that in 2007 in the lead to the 2008 Olympic Games, the number of environmental petitions has dropped but since then it is back to its high level of around 70,000 per year (see Figure 5). This shows active awareness and engagement with environmental issues on the part of the Chinese population but it also demonstrates the multitude of existent or potential problems. The number of environmental proposals has been on the raise since 2006 across all parts of China (see Figure 6).

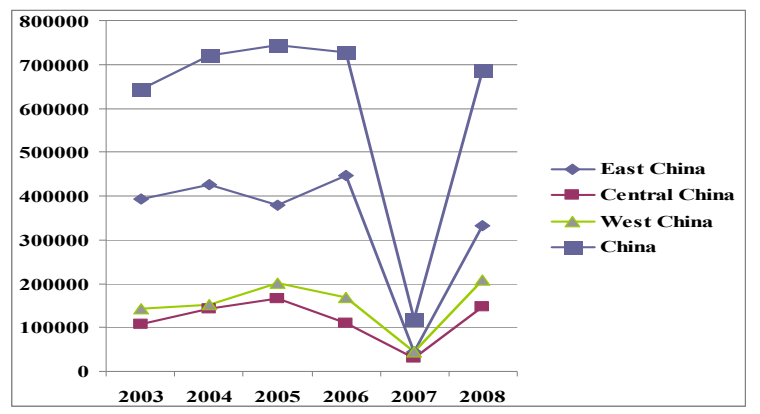

Figure 5. Environmental petitions in China, 2003-2008

Source: Compiled from http://www.dushu.com

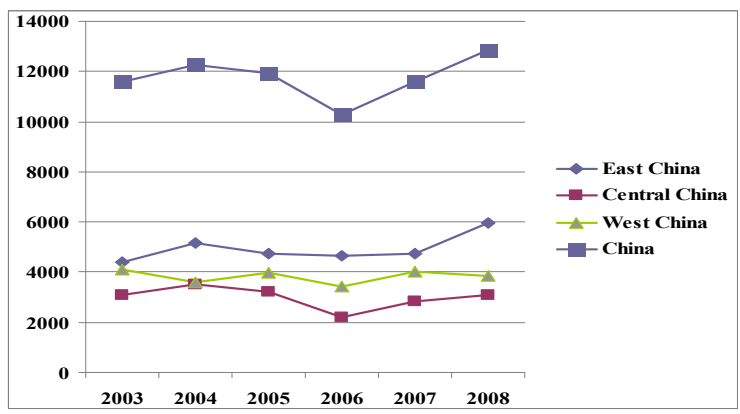

Figure 6. Environmental proposals submitted by NPC and CPPCC, 2003-2008

Source: Compiled from http://www.dushu.com

Enhancing the positive attitudes and behaviours of people towards the environment is very important. According to McKinsey Global Institute (2008, p 34), "[t]o a large extent, carbon emissions are the product of billions of decisions made by individual managers and consumers around the world every day". Therefore, education on carbon reduction and environmental protection becomes very important. The massive carbon emissions generated by China require its citizens and industries to have a sound level of environmental awareness. Chinese people need to be educated about the natural environment and its fragility.

There are many ways to deliver such education including from training courses for targeted groups of people to specialised university courses. These can be achieved through international cooperation. For example, in 2009 the Ministry of Education, WWF and BP celebrated their successful completion of the Environmental Educators' Initiative (EEI), a ten-year joint environmental education program in China between the three parties (BP, 2009). The promotion of a healthy environment helps to maintain a quality economic development. Industries in China can gain competitive advantage through proper management of the environment. Environmental education can help raise China's environmental standards and certain regulations can be strengthened. If proper environmental education is delivered in place, the country's transformation towards a low carbon economy will be smooth and easier. Although China has established 
environmental protection organisations under governments at all levels and formed a complete environmental control system (State Council Information Office of the PRC, 2006), there is much more to be done.

\section{TRANSITION TO A LOW-CARBON ECONOMY IN A CONGRUENT WAY}

China has emerged as an economic and political power relatively recently but its history and culture stretch over millennia. How can China achieve a low-carbon economy by learning from the past and the country's rich traditions? There are a lot of positive Chinese cultural elements of harmony that can be very useful in this transformation. For example, the Chinese governmental and non-government organisations can be involved in developing a better relationship between people and their natural environment by absorbing nourishment from the Chinese cultural gene of Confucianism. More than 2500 years ago, Confucius advocated the unity of humankind with nature and other ideas to encourage the harmonious relationship between human activities and the natural environment. Confucius' thought formed the basic consideration for the protection of the natural environmental.

Under the pressure of global warming, the world, including China, is desperately seeking solutions. There is a need for China to explore the wisdom of Confucius and other oriental ideas for environmental education and draw implications for solving problems related to climate change. In fact, Confucianism is becoming more and more influential in China and Confucian philosophy can provide useful guidelines for achieving environmental publicity. China's heritage is rich in Confucian culture and other thoughts of philosophy and educators and they all can contribute towards a harmonious transformation.

\section{CONCLUSION}

According to Huang et al. (2010), "environmental issues are becoming increasingly important in China, attracting heightened attention from policy stakeholders". China has already made considerable progress in enhancing environmental education and awareness. The country is willing to be well advanced in establishing effective educational programs for facilitating the shift to a low-carbon economy. It needs to significantly improve its domestic environmental conditions by reducing environmental deterioration and the pressure on energy resources due to the large population, continuing industrialisation and urbanisation. Solving environmental problems and reducing carbon emissions, improving environmental awareness are the key issues for the Chinese government.

An important development in recent years is the expanded role of China's environmental NGOs in the educational system. They have been able to close the gap left open by the rapid development of the country. However, their capacity for activities is not strong enough without cooperation across all sectors of society. Although they encourage actively the local public participation in environmental protection, environmental NGOs often lack essential skills and requirements such as legal knowledge, financial and social support. China's central and local governments should more efficiently adjust public policy directions and promote the development of a low-carbon economic model through providing timely educational programs. The Chinese government and industry need to cooperate with the environmental NGOs as well as the media to build a sound base of supporters and public trustees. It is also crucial to have a bigger role for government in environmental education, legislation and protection for the adoption of a low-carbon economy.

China has made efforts to tackle climate change and to adjust its response to the capacity of low-carbon economic development. It has set high targets for its $12^{\text {th }}$ Five-year Plan and prepared a more balanced model of development. It aims at continuing the stable and relatively fast economic growth and improving the prosperity of its citizens, but also for achieving these in a healthier ecological environment. China's recent policy shift towards a low-carbon economy will help the nation to alleviate the global environmental issues and cooperate with the rest of the world to tackle climate change. Although China has established a complete environmental management system, this country is still in need of more effective implementation of environmental management, laws and regulations. It also needs to draw on its ancient wisdom and culture to achieve such ambitious tasks and transformation in a smooth, peaceful and a harmonious way.

\section{ACKNOWLEDGEMENT}

The two authors want to acknowledge the financial support of the Australian Research Council. They are also extremely thankful to Ruiyue Jia for his help with data collection and analysis. 


\section{REFERENCES}

Australian Government (2011). Australia and China to co-operate on building low-carbon economies. http://www.climatechange.gov.au/en/minister/gregcombet/2011/mediareleases/March/mr20110329.aspx, accessed April 7, 2011.

BP (2009). Ten Years of Environmental Education in China http://www.bp.com/genericarticle.do? categoryId=9004958\&contentId=7053851, accessed April 11, 2011.

China Daily (2011). China: Environment must not be sacrificed for rapid development. http://www.chinadaily.com.cn/usa/china/2011-02/28/content_12086962.htm, accessed February 29, 2011.

Harris, P. (2006). Environmental perspectives and behavior in China: Synopsis and bibliography. Environment and Behavior 38(1): 5-21.

Hickson, K. (2009). The ABC of Carbon: Issues and Opportunities in the Global Climate Change Environment. ABC Carbon, Toowong.

Huang, X., D. Zhao, C.G. Brown, Y. Wu and S.A. Waldron (2010). Environmental issues and policy priorities in China: A content analysis of government documents. China: An International Journal 8(2), 220-246.

International Energy Agency (2009). $\mathrm{CO}_{2}$ Emissions from Fuel Combustion Highlights. www.iea.org/co2highlights/CO2highlights.pdf, accessed April 7, 2011.

International Energy Agency (2010). $\mathrm{CO}_{2}$ Emissions from Fuel Combustion Highlights. www.iea.org/co2highlights/CO2highlights.pdf, accessed April 7, 2011.

McBeath, J. and J. McBeath (2009). Environmental Education in China: A Preliminary Comparative Assessment. www.ccny.cuny.edu/aacs/2009conference/Jerry_and_Jenifer_McBeath.doc, accessed February 19, 2011.

McKinsey Global Institute (2008). The Carbon Productivity Change: Curbing Climate Change and Sustaining Economic Growth. McKinsey \& Company, Sydney.

National Development and Reform Commission (2009). China's Policies and Actions for Addressing Climate Change - the Progress Report 2009. Beijing.

National Environmental Protection Bureau, CPC Central Committee Propaganda Department and National Education Committee (1996). Platform for Action, the National Environmental Publicity and Education. http://www.chinalawedu.com/news/1200/22598/22603/22683/2006/3/sh248128012136002546-0.htm, accessed April 7, 2011.

Parlour, J.W. and S. Schatzow (1978). The mass media and public concern for environmental problems in Canada, 1960-1972. International Journal of Environmental Studies 13(1): 9-17.

Qing, T. (2004). Historical review of environmental education in China. Chinese Education and Society 37(3): 34-38.

State Council Information Office of the PRC (2006). The Environmental Protection in China (1996-2005). http://www.gov.cn/zwgk/2006-06/05/content_300288.htm, accessed April 7, 2011.

Uchida, T. (2007). Information disclosure policies: When do they bring environmental improvements? International Advances in Economic Research 13(1): 47-64.

United Nations Development Programme (UNDP) China (2009). Human Development Report 2009/10-Key Findings, China and a Sustainable Future Towards a Low Carbon Economy and Society. www.undp.org.cn, accessed April 7, 2011.

United Nations Development Programme (UNDP) China (2010). China Human Development Report 2009/10: China and a Sustainable Future towards a Low Carbon Economy and Society, China Publishing Group Corporation China Translation \& Publishing Corporation China. www.undp.org.cn/pubs/nhdr/nhdr2010e.pdf, accessed April 7, 2011.

United Nations Environment Programme (UNEP) (2009). Expo 2010: Shanghai, China. http://www.unep.org/publications/contents/pub_details_search.asp?ID=4040, accessed April 7, 2011.

Wei, J., D. Zhao, and D. Marinova (2010). What determines a community to choose the pathway to sustainable development in China? Local Environment 5(9): 831-850.

Wu, Y. (2010). Regional environmental performance and its determinants in China. China and World Economy 18(3): 73-89.

Xinhua Net (2009). China's Commitment of Reduction of the Intensity of Carbon Dioxide Emissions per unit of GDP in 2020 by 40-45 percent Compared to the 2005 Level. http://news.xinhuanet.com/politics/200911/26/content_12544442.htm, accessed April 7, 2011.

$\mathrm{Xu}, \mathrm{K}$. (2009). Review of recent studies on environmental NGOs in China: Progress, problems and prospects. Issues of Contemporary World Socialism, 6(1), http://www.krics.sdu.edu.cn/php/article.php?articleid=571, accessed April 11, 2011. 